\title{
Optimization of a chitosan solution as potential carrier for the incorporation of Santolina chamaecyparissus L. solid by-product in an edible vegetal coating on 'Manchego' cheese
}

\author{
Gonzalo Ortiz de Elguea-Culebras ${ }^{\mathrm{a}, \mathrm{b}}$, Ana I. Bourbon ${ }^{\mathrm{c}, \mathrm{d}}$, Maria J. Costa ${ }^{\mathrm{c}, \mathrm{d}}$, Nuria Muñoz-Tebar ${ }^{\mathrm{a}}$, \\ Manuel Carmona $^{\mathrm{e}}$, Ana Molina ${ }^{\mathrm{a}}$, Raúl Sánchez-Vioque ${ }^{\mathrm{b}, \mathrm{f}}$, M. Isabel Berruga ${ }^{\mathrm{a}, *}$, \\ António A. Vicente ${ }^{\mathrm{c}}$

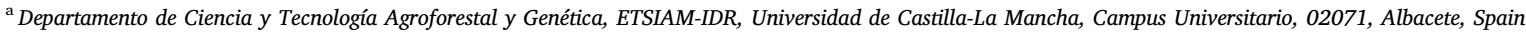 \\ ${ }^{\mathrm{b}}$ Centro de Investigación Agroforestal de Albaladejito (IRIAF-JCCM), Carretera Toledo-Cuenca km 174, 16194, Cuenca, Spain

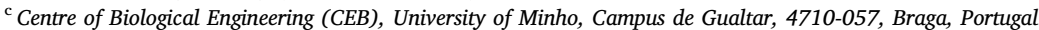 \\ ${ }^{\mathrm{d}}$ International Iberian Nanotechnology Laboratory (INL), Av. Mestre José Veiga, 4715-330, Braga, Portugal \\ e Universidad Europea de Madrid, School of Architecture, Engineering and Design, Food Technology Lab, Madrid, Spain \\ ${ }_{\mathrm{f}}^{\mathrm{f}}$ Instituto de Recursos Humanos para la Ciencia y la Tecnología (INCRECYT), Fundación Parque Científico y Tecnológico de Castilla-La Mancha, Paseo de la Innovación 1, \\ 02006, Albacete, Spain
}

\section{A R T I C L E I N F O}

\section{Keywords:}

Edible coating

Natural bioactive extract

Manchego cheese

Santolina chamaecyparissus L.

Industrial by-product

\begin{abstract}
A B S T R A C T
The occurrence of microorganisms in cheese rinds provokes important economic losses in cheese factories. This may be solved in an environmentally-friendly manner using different edible and biodegradable active coatings. Aromatic plants are particularly well placed to be included in such coatings as they contain different secondary metabolites with beneficial biological properties that could be transferred to the product. In this work, a chitosan solution was optimized for the incorporation of an extract from cotton lavender or Santolina chamaecyparissus L. solid by-product in an edible vegetal coating on 'Manchego' cheese. Namely, the antifungal and antioxidant properties of coatings, as well as the physical characteristics of resulting films were studied. Results showed that the addition of the extract confers significant antioxidant capacities to the coating, increases its antifungal capacities and enhances some physical properties. In addition, the use of coatings containing $S$. chamaecyparissus by-products is a novel strategy leading to a better management of these residues from the essential oil industry sector.
\end{abstract}

\section{Introduction}

The presence of fungi is responsible for the spoilage of cheese rinds and for the production of cracks and spots in their inner mass. The most common genus of molds in cheeses are probably Penicillium and Aspergillus (Hymery et al., 2014; Serrano-Martinez, 1997). In addition, these microorganisms are responsible for the release of mycotoxins such as ochratoxin A (OCA) by Penicillium verrucosum (Jeršek et al., 2014) or aflatoxins by Aspergillus species (Hymery et al., 2014). This specially occurs in long time ripening cheeses (hard and semi-hard), such as the Manchego PDO (Serrano-Martinez, 1997). This cheese is processed with ovine milk in the location of Castilla-La Mancha (Spain), regulated under the Regulation (EU) No 129/2012 of 13 February 2012 and elaborated artisanal or industrially depending on the use of raw or pasteurized milk, respectively (Cabezas, Sánchez, Poveda, Seseña, \& Palop, 2007). Accordingly, cheese producers look for different strategies with the aim of avoiding fungal appearance, like the employment of natamycin (Ollé Resa, Jagus, \& Gerschenson, 2014) or the application of non-edible plastic coatings. However, such substances may cause certain negative effects on humans or the environment and consequently, consumer organizations claim for their replacement.

Different aromatic plants have been proposed to solve foodborne contamination due to their potential bioactive capacities (Voon, Bhat, \& Rusul, 2012). Additionally, Kastrup-Dalsgaard et al. (2010) have also observed potential photo-oxidation reactions on cheese rinds, so the use of different innocuous antioxidants and darker coatings should also be considered when developing cheese preservation systems. Essential oils are widely known for their biological effects, but may cause changes in

\footnotetext{
* Corresponding author.

E-mail address: MariaIsabel.Berruga@uclm.es (M.I. Berruga).
} 
original flavours of cheeses resulting in a possible rejection by consumers. Besides, aromatic components can volatilize from edible coatings leading to a decrease over time of the microbiological effects (Ponce, Roura, del Valle, \& Moreira, 2008). By contrast, phenolic compounds have been previously proposed for their application in food products as they provide color, certain astringency, oxidative stability and antifungal effects to many types of foods (Rutz et al., 2013; Zabka \& Pavela, 2013). In comparison with the fresh aromatic plant, the distilled by-product of its counterpart is more suitable for this purpose as it is practically devoid of essential oils but retains most of the phenolic fraction. In such a way, this by-product may also increase its addedvalue (Sánchez-Vioque et al., 2013). In addition, the use of such byproducts for the development of food preservation systems is encouraging since they have previously demonstrated antifungal and antioxidant capacities, such as Santolina chamaecyparissus (cotton lavender), Satureja montana (winter savory) or Hyssopus officinalis (hyssop) (Džamić et al., 2013; Ortiz de Elguea-Culebras, 2017a; Ortiz de Elguea-Culebras et al., 2016). The application of active compounds present in such residues may well be through their incorporation in diverse biodegradable and edible matrices as, among others, galactomannan, sodium alginate or particularly chitosan (Costa, Maciel, Teixeira, Vicente, \& Cerqueira, 2018), which has demonstrated good preservative capacities on sheep's (Cerqueira et al., 2009) and goat's (Cano-Embuena et al., 2017) cheeses. Furthermore, chitosan has previously demonstrated capacities as carrier for the incorporation of different vegetal extracts (Bonilla \& Sobral, 2016; Kalaycıŏlu, Torlak, Akın-Evingür, Özen, \& Erim, 2017; Shahbazi, 2017; SharafatiChaleshtori \& Sharafati-Chaleshtori, 2017; Siripatrawan \& Harte, 2010) and incorporated as GRAS (Generally Recognized as Safe) by the Food and Drug Administration (FDA, 2002) and in the Union list of novel foods under the Regulation (EU) No 2017/2470 of 20 December 2017.

The aim of the present work is to study the viability of a chitosan solution as a potential carrier for the incorporation of an aromatic plant solid by-product in an edible coating on Manchego cheese. In this regard, the ethanolic extract of the solid residue resultant from the industrial distillation of the Santolina chamaecyparissus L. was selected among others due to its antifungal and antioxidant capacities demonstrated in a previous study (Ortiz de Elguea-Culebras, 2017a). Accordingly, the biological capacities and the physical properties of the generated coating were assayed. Our purpose was to explore the valorization of essential oil industry by-products for the development of natural preservation systems on cheeses.

\section{Materials and methods}

\subsection{Materials}

Chitosan with high molecular weight and 95\% of degree of deacetylation (DD) was purchased from Golden-Shell Biochemical Co., Ltd. (Yuhuan, China). Pure glycerol, methanol (analitycal grade) and ethanol (food grade) were obtained from Panreac (Barcelona, Spain). Tween 20, butylated hydroxytoluene (BHT), 1,1-diphenyl-2-picrylhydrazyl (DPPH) and linoleic acid were purchased from Sigma Aldrich (St. Louis, MO, USA). L( $\beta$ )-lactic acid (90\%) was obtained from AppliChem (Darmstadt, Germany) and bromonaphtalene from Merck (Darmstadt, Germany). The selected cheese was an artisanal 30 days pressed sheep's Manchego cheese without any surface treatment (natural rind) acquired from a local cheese factory (Albacete, Spain).

\subsection{Vegetal material}

The solid by-product resultant from the industrial distillation of Santolina chamaecyparissus L. was gathered and extracted in a Soxhlet apparatus with ethanol, as described in Ortiz de Elguea-Culebras, Berruga, Santana-Méridas, Herraiz-Peñalver, and Sánchez-Vioque (2017b), obtaining thus the $S$. chamaecyparissus Industrial Solid Residue
Extract (SISRE). The phenolic characterization of the SISRE was also reported in Ortiz de Elguea-Culebras et al. (2017b).

\subsection{Analysis of cheese content}

The cheese was analyzed for its composition in a NIRS FoodScan (Foss, Hilleroed, Denmark) based on Licón, Carmona, Molina, and Berruga (2012), and for its physical characteristics as follows: (1) colour in a Minolta CR-400 colorimeter (Konica Minolta, Japan) using the CIE $1976 \mathrm{~L}^{*}, a^{*}, b^{*}$ method; (2) water activity was measured in a LabTouch aW-meter (Novasina, Zurich, Switzerland); (3) $\mathrm{pH}$ in an EDGE Blu pH-meter (Hanna Instruments, Guipúzcoa, Spain). The analyses were performed in triplicate on the rind and inner mass of the cheese. Additionally, the surface tension of the cheese rind was measured at room temperature by the sessile drop method in a System OCA20 (DATAPhysics Instruments, GmbH, Germany) with 10 droplets of ultrapure water, glycerol and bromonaphtalene according to Cerqueira et al. (2009). The drop volume was of $2 \mu \mathrm{L}$ at a drip rate of $1 \mu \mathrm{L} / \mathrm{s}$ and after $15 \mathrm{~s}$, the formed angles were calculated with the software. Finally, work of adhesion $(W a)$, work of cohesion $(W c)$ and spreading coefficient $(W s)$ were calculated as also reported in Cerqueira et al. (2009) and expressed in $\mathrm{mJ} \mathrm{m}^{-2}$. Additionally, the density of cheese was determined by the water displacement technique (Owolarafe, Olabige, \& Faborode, 2007).

\subsection{Optimization of the chitosan solution}

The chitosan solution was prepared based on Martins, Cerqueira, and Vicente (2012), with some modifications. Tween 20 was used instead of Tween 80 due to the possibility of microbial growth in the presence of such surfactant (Nielsen, Kjems, Mygind, Snabe, \& Meyer, 2016). The addition of glycerol was considered to enhance the plasticizing properties of coatings containing Tween 20 (Ziani, Oses, Coma, \& Maté, 2008). In brief, chitosan (1.5\%, w/v) and L( $\beta)$-lactic acid (1\%, v/ v) were added to water and stirred overnight at room temperature. Then, two concentrations of glycerol, 10 and $30 \%$ (w/w of chitosan powder) and two of Tween 20, 5 and 15\% (w/w of chitosan powder) were also added to the mixture and stirred again. The best formulation was selected based in the wettability parameter $(W s)$ (target value: $W s \approx 0$ ) on the cheese, using the sessile drop method, as described in section 2.3. The surface tension of the coatings was determined with the Ring method as described in Gudiña et al. (2016) using a KRÜSS K20 Tensiometer (KRÜSS GmbH, Germany) equipped with a $1.9 \mathrm{~cm}$ du Noüy platinum ring. The optimized formulation for the Manchego cheese coating (Table 1 ) contained $1.5 \%(\mathrm{w} / \mathrm{v})$ chitosan, $1 \% \mathrm{~L}-(\beta)$-lactic acid, $30 \%$ glycerol (w/w of chitosan powder) and $15 \%$ Tween $20(\mathrm{w} / \mathrm{w}$ of chitosan powder).

\subsection{Preparation of the SISRE coating}

The SISRE was dissolved in an ethanol:water (8:2) solution by stirring overnight at room termperature. Subsequently, dissolved SISRE

\section{Table 1}

Optimization of the carrier chitosan solution. Data are the mean \pm standard deviation of three measurements. Different letters denote statistical differences among coatings ( $\mathrm{p}<0.05$, ANOVA). Optimized results for Wa: work of adhesion $\left(\mathrm{mJ} \mathrm{m}^{-2}\right)$; Wc: work of cohesion $\left(\mathrm{mJ} \mathrm{m}^{-2}\right)$; Ws: spreading coefficient $\left(\mathrm{mJ} \mathrm{m}^{-2}\right)$ are in bold.

\begin{tabular}{|c|c|c|c|c|}
\hline Glycerol (\%) & $\begin{array}{l}\text { Tween } \\
20 \text { (\%) }\end{array}$ & $W a$ & $W c$ & Ws \\
\hline \multirow[t]{2}{*}{10} & 5 & $42.36 \pm 3.18^{\mathrm{a}}$ & $70.60 \pm 0.00^{\mathrm{a}}$ & $-28.24 \pm 3.18^{\mathrm{a}}$ \\
\hline & 15 & $49.57 \pm 4.59^{\mathrm{b}}$ & $70.20 \pm 0.00^{\mathrm{b}}$ & $-20.63 \pm 4.59^{b}$ \\
\hline \multirow[t]{2}{*}{30} & 5 & $45.11 \pm 5.09^{\mathrm{ab}}$ & $72.00 \pm 0.00^{c}$ & $-26.89 \pm 5.09^{\mathrm{a}}$ \\
\hline & 15 & $56.57 \pm 4.57^{c}$ & $69.80 \pm 0.00^{\mathrm{d}}$ & $-13.23 \pm 4.57^{\circ}$ \\
\hline
\end{tabular}


was mixed with the previously optimized chitosan solution at a ratio of 2:8 (SISRE solution:chitosan solution) and stirred for $5 \mathrm{~h}$ at room temperature to yield the SISRE coating as described in Yoksan, Jirawutthiwongchai, and Arpo (2010). Finally, the SISRE coating was homogenized at a speed of $10,000 \mathrm{rpm}$ for $4 \mathrm{~min}$ in an T-25 digital Ultra-turrax (IKA, Wilmington, NC, USA) (Martins et al., 2012). The final concentration of the SISRE in the chitosan solution was $1 \%(\mathrm{w} / \mathrm{v})$. As control coating, water at the proportion of 2:8 (water:chitosan solution) was added to the optimized chitosan solution.

\subsection{Wettability, surface tension, $\mathrm{pH}$ and density of coatings}

The capacity of the SISRE and control coatings to spread over the cheese rind was performed over the Manchego cheese by the sessile drop method, previously described in section 2.3. The surface tension of the coatings was determined with the Ring method (Gudiña et al., 2016). An Edge Blu pH-meter (Hanna Instruments, Guipúzcoa, Spain) was used for measuring the $\mathrm{pH}$, whereas density was calculated by weighing $1 \mathrm{~mL}$ of the liquid in a precision balance and expressed as $\mathrm{g} \mathrm{cm}^{-3}$. All assays were performed in triplicate.

\subsection{Biological capacities of coatings}

\subsubsection{Antifungal}

The evaluation of the antifungal capacities of the coatings was performed by the radial growth test as described in Quintana-Obregón, Plascencia-Jatomea, Sánchez-Mariñez, Rosas-Burgos, and Cortez-Rocha (2010) and Plascencia-Jatomea, Viniegra, Olayo, Castillo-Ortega, and Shirai (2003) with some modifications. Aspergillus flavus CECT 2687, Penicillium roqueforti CECT 20485 and P. verrucosum CECT 2906 were elected for antimicrobial tests, as being the most frequent fungal contaminants of Manchego cheeses as reviewed by Serrano-Martinez (1997). In brief, approximately $20 \mathrm{~mL}$ of potato dextrose agar (PDA) were spread over the surface of sterile Petri plates. Once the agar solidified, $1 \mathrm{~mL}$ of the coatings were spread on it and water was let to evaporate for at least $24 \mathrm{~h}$. Petri dishes with only PDA were used as negative control. Then, a $0.6 \mathrm{~cm}$ diameter well was performed in the center of the plates and inoculated with $10 \mu \mathrm{L}$ of the assayed fungi at a fixed concentration calculated from absorbance of around $1 \times 10^{4} \mathrm{CFU} / \mathrm{mL}$ as explained in Ortiz de Elguea-Culebras et al. (2016). Tests were performed in triplicate and the cultures in the Petri dishes were incubated upside down at a controlled temperature of $25 \pm 1{ }^{\circ} \mathrm{C}$. The image of plates was taken in a Countermat Flash 4.2 (IUL S.A., Barcelona, Spain) and the radial growth area was measured after the first $72 \mathrm{~h}$ and each $24 \mathrm{~h}$ during 7 days by means of the software Image $\mathrm{J}$ Version 1.37 r, 2010 (http://rsb.info.nih.gov./ij/). Growth inhibition were calculated according to the formula described in PlascenciaJatomea et al. (2003) and shown in Eq. (1):

Growht inhibition $(\%)=\left(\frac{X c-X i}{X c}\right) \times 100$

where $X_{c}$ was the colony radius of the blank (PDA) and $X_{i}$ that of the coatings.

\subsubsection{Antioxidant}

The DPPH radical-scavenging activity was assayed as described in Ortiz de Elguea-Culebras et al. (2017b). Coating samples of $0.5 \mathrm{~mL}$ were mixed with $2.5 \mathrm{~mL}$ of DPPH in methanol $(0.04 \mathrm{mg} / \mathrm{mL})$, incubated $1 \mathrm{~h}$ at room temperature and measured at a wavelength of $517 \mathrm{~nm}$. Distilled water and gallic acid $(0.5 \mathrm{mg} / \mathrm{mL})$ were used as control and as standard antioxidant of the assay, respectively. The inhibition activity of DPPH radicals was calculated as in Eq. (2):

Inhibition activity $(\%)=\left(\frac{A_{0}-A_{1}}{A_{0}}\right) \times 100$ where $A_{0}$ was the absorbance of the negative control, and $A_{1}$ was the absorbance of the samples. The concentration of sample required to reduce $50 \%$ of DPPH radicals $\left(I C_{50}\right)$ was calculated from linear regression analysis. Low $I C_{50}$ values indicates high radical-scavenging activity.

A linoleic acid model system was also used to investigate the antioxidant activity of the coating samples (Sánchez-Vioque et al., 2015). This model mimics the oxidation of unsaturated lipids along time, and evaluates the capacity of a sample to delay it by monitoring the formation of oxidation compounds (conjugated dienes, lipid hydroperoxides and carbonyl groups) each $24 \mathrm{~h}$. Coating samples of $0.3 \mathrm{~mL}$ were mixed in screwed tubes containing $5.7 \mathrm{~mL}$ of distilled water and $5 \mu \mathrm{L}$ of linoleic acid, thoroughly stirred, and incubated at $60^{\circ} \mathrm{C}$ for 7 days. The final concentration in the tubes for the SISRE coating was of $500 \mu \mathrm{g} / \mathrm{mL}$. Distilled water and BHT $(8.3 \mu \mathrm{g} / \mathrm{mL})$ were used as control and as antioxidant standard of the assay, respectively. The lipid oxidation was expressed as the percentage of formation of oxidation compounds with respect to the control (100\% oxidation).

\subsection{Physical properties of films}

The SISRE and control film forming solutions were cast into Petri dishes, dried in a ventilated chamber at $35^{\circ} \mathrm{C}$ for $24 \mathrm{~h}$ and the dry films maintained in incubators at 53\% RH (relative humidity) and at room temperature $\left(22^{\circ} \mathrm{C}\right)$. The subsequent tests were also performed at room temperature:

\subsubsection{Moisture, water solubility and swelling index}

To analyze the moisture, film circles of $2 \mathrm{~cm}$ of diameter were firstly weighed, dried for $24 \mathrm{~h}$ at $105^{\circ} \mathrm{C}$ and weighed again. Moisture content was determined in triplicate for each film as in Eq. (3):

Moisture content $(\%)=\left(\frac{M_{0}-M}{M_{0}}\right) \times 100$

where $M_{O}$ and $M$ were respectively the masses before and after drying. The water solubility was determined by placing the dry circles in beakers containing $50 \mathrm{~mL}$ of distilled water and placed in an orbital agitator at $150 \mathrm{rpm}$ for $24 \mathrm{~h}$. Insolubilized films were then dried at $105^{\circ} \mathrm{C}$ for $24 \mathrm{~h}$, weighed, and solubility was calculated in triplicate for each film as in Eq. (4):

Solubility $(\%)=\left(\frac{S_{0}-S}{S_{0}}\right) \times 100$

where $S_{O}$ was the initial dry mass and $\mathrm{S}$ was the insoluble dry mass of the film. Finally, to analyze the swelling capacities, film squares of $4 \mathrm{~cm}^{2}$ were weighed and immersed in beakers with $100 \mathrm{~mL}$ of distilled water for $24 \mathrm{~h}$. Subsequently, water was removed from the films with filter paper and weighed again and swelling calculated in triplicate for each film as in Eq. (5):

Swelling $(\%)=\left(\frac{S W-S W_{0}}{S W_{0}}\right) \times 100$

where $S W$ is the weight of the swollen film and $S W_{O}$ that of the initial film.

\subsubsection{Color, opacity and transparency}

The color was measured with a Minolta CR-400 colorimeter, as described in section 2.3. A white standard color plate was used as background for color measurements of the films. Ten measures were performed for each film in triplicate. Chroma $\left(C^{*}\right)$ and hue angle were calculated attending to the equations reported in Souza et al. (2017). Opacity was also determined with a Minolta CR-400 colorimeter according to the Hunter Lab method. The opacity was calculated with 10 measurements for each film in triplicate as in Eq. (6): 
$\operatorname{Opacity}(\%)=\left(\frac{Y_{b}}{Y_{w}}\right) \times 100$

where $Y_{b}$ and $Y_{w}$ were the opacity of the samples on a black and white standard plates, respectively (Costa et al., 2015). Transparency was calculated by measuring rectangular sample films by the direct reading in quartz spectrophotometer cuvettes and determined in triplicate as \% transmittance by spectrum scanning (wavelengths between 200 and $1000 \mathrm{~nm}$ ) in an UV/Vis Helios $\alpha$ (ThermoFisher Scientific Inc., MA, USA) spectrophotometer using air as blank (Souza et al., 2017).

\subsubsection{Thickness}

The thicknesses of the films (mm) was measured at ten different points for each sample in triplicate using a digital micrometer (No. 2935, Mitutoyo, Japan) with $\pm 0.001 \mathrm{~mm}$ accuracy.

\subsubsection{Mechanical properties}

Mechanical properties were determined as described by the ASTM D882-10 (ASTM D882-10; 2010) in a TA.HDPlus texturometer (Stable Micro Systems, United Kingdom). Samples were clamped between the A/MTG tensile grips with an initial distance of $100 \mathrm{~mm}$. The force and deformation were recorded during extension at $50 \mathrm{~mm} / \mathrm{min}$. Tensile strength (TS) and elongation-at-break (EAB) were expressed in MPa and $\%$ elongation, respectively. Three strips were measured for each film in triplicate.

\subsubsection{Thermal properties}

The thermal properties of films were determined by Differential Scanning Calorimetry (DSC). Measurements were performed in a Shimadzu DSC-50 (Shimadzu Corporation, Kyoto, Japan). Scans ranged from 20 to $250^{\circ} \mathrm{C}$ at a rate of $10^{\circ} \mathrm{C} / \mathrm{min}$ under a nitrogen atmosphere. Melting temperature $\left(T_{m}\right)$ and specific enthalpy $\left(\Delta h_{m}\right)$ were measured in duplicate for each film and expressed respectively in ${ }^{\circ} \mathrm{C}$ and $\mathrm{J} \mathrm{g}^{-1}$.

\subsubsection{Water vapor permeability (WVP)}

The capacity of water to permeate through the film was determined gravimetrically based on the ASTM E96/E96M - 16 (ASTM E96/ E96M-16, 2016). In brief, dessicated $45 \mathrm{~mm}$ diameter circles were sealed on cups filled with distilled water and placed inside a dessicator with silica gel, containing a fan inside to enhance uniformity conditions. Samples were weighed at intervals of $2 \mathrm{~h}$ for $10 \mathrm{~h}$ in order to monitor weight loss over time. Water vapor permeability (WVP; WVP ( $g$ $\left.\mathrm{s}^{-1} \mathrm{~m}^{-1} \mathrm{~Pa}^{-1}\right)$ ) was determined in triplicate for each film and calculated as in Eq. (7):

$W V P=\left(\frac{W V T R \times L}{\Delta P}\right)$

where WVTR is the water vapor transmission rate obtained from the linear regression of the weight loss $\left(\mathrm{g} \mathrm{m}^{-2} \mathrm{~s}^{-1}\right), L$ is the film thickness (m), $\Delta P$ is the water vapor partial pressure difference across the two sides of the film $(2337 \mathrm{~Pa})$ and the permeation area was calculated in $5.2 \times 10^{-3} \mathrm{~m}^{2}$.

\subsubsection{Surface tension of films}

To determine the hydrophobicity or hydrophilicity of films, 10 droplets of ultrapure water were placed on the films by the sessile drop method, as described in section 2.3. All measures were performed in triplicate for each film.

\subsection{Oxygen and carbon dioxide exchange rates}

Respiration ratios were monitored by placing the cheese into a hermetic reactor and measuring the reduction of $\mathrm{O}_{2}$ and the production of $\mathrm{CO}_{2}$ by gas chromatography (GC) according to the closed system method with air as initial atmosphere as described by Cerqueira et al. (2009) with modifications. Cheese cubes without rind of approximately
$300 \mathrm{~cm}^{3}$ were covered with the control and SISRE coating and placed inside a hermetic reactor and incubated at $10 \pm 0.5^{\circ} \mathrm{C}$. Additionally, an uncoated cheese cube was used as control. The atmosphere inside the reactor was measured in triplicate by extracting $500 \mu \mathrm{L}$ of gas with a Hamilton syringe through the septum placed at the reactor lid. Gas exchange was determined using a 456-GC Bruker gas chromatograph (Bruker, Karlsruhe, Germany) with the oven at $35^{\circ} \mathrm{C}$. A Rt-Q-bond $30 \mathrm{~m} \times 0.53 \mathrm{~mm}$ i.d. x $20 \mu \mathrm{m}$ thickness column (Restek Corp., Bellefonte, PA, USA) was used for the detection of $\mathrm{O}_{2}$, using argon as carrier gas at $60 \mathrm{~mL} / \mathrm{min}$ and with the injector at $100^{\circ} \mathrm{C}$. Analysis of $\mathrm{CO}_{2}$ was performed in a Molesieve $13 \times 6 \mathrm{ft}$. $2.1 \mathrm{~mm} \times 60 / 80$ mesh molecular sieve column (Restek Corp., Bellefonte, PA, USA), using helium at a flow of $4 \mathrm{~mL} / \mathrm{min}$ with the injector at $80^{\circ} \mathrm{C}$. The split ratio was of $1: 10$, the conductivity detectors were set at $130^{\circ} \mathrm{C}$ and gases were recorded in $\mu \mathrm{V} / \mathrm{min}$. A commercial gas mixture containing $10 \% \mathrm{CO}_{2}, 20 \% \mathrm{O}_{2}$ and $70 \% \mathrm{~N}_{2}$ was used as a standard for the calibration. Tests were recorded each $24 \mathrm{~h}$ for 15 days. The $\mathrm{O}_{2}$ consumption and $\mathrm{CO}_{2}$ production rates were determined using the formulas described in Cerqueira et al. (2009). Finally, a photograph of the cheeses was taken in order to determine visually their final aspect.

\subsubsection{Weight loss and relative humidity}

These parameters were calculated for each coated and uncoated cheeses. Weight loss was calculated as in Eq. (8):

Weight loss $(\%)=\left(\frac{W_{0}-W}{W_{0}}\right) x 100$

where $W_{o}$ and $W$ were the masses of the cheese before and after 15 days of incubation, respectively. Relative humidity and termperature were controlled using an iButton sensor (Maxim Integrated, San José, CA, USA) into the reactor.

\subsection{Statistical analyses}

Statistical differences $(p<0.05)$ among physic-chemical analysis of cheese, physical, antifungal and antioxidant properties of coatings, film parameters and respiration ratios of coated cheeses were determined by the post-hoc HSD Tukey's multiple ranged test from oneway ANOVA by the SPSS Statistics 23 (IBM Corp., New York, NY, USA) at a $95 \%$ confidence level.

\section{Results and discussion}

\subsection{Cheese characterization}

The characterization of the artisanal Manchego cheese is shown in Table 2. The analytical composition showed statistical differences $(p<0.05)$ between the rind and the inner part of the cheese, specially regarding the content in \%DM (dry matter) and salt with differences of 1.15 and $0.25 \%$, respectively. Such differences may well be attributed to a higher water loss of the rind and to a gradual diffusion of salt from the surface to the inner mass of the cheese, since this type of cheese is salted by inmersion into brine. In relation to the Manchego PDO regulations (Regulation (EU) No 129/2012 of 13 February 2012), the cheese composition complied accurately with the current applicable standards. Cabezas et al. (2007) studied the chemical composition of an artisanal Manchego cheese, reporting alike results for fat and salt, but lower in DM (61.11\%) in the inner mass of a Manchego cheese at 1 month of ripening. These authors studied the variations of the cheese along time, from 0 to 240 days, observing special dissimilarities regarding the salt and DM content, related to the loss of water throughout the ripening. The $\mathrm{pH}$ value showed a result within the required value of the Manchego PDO and comparable to that reported by Cabezas et al. (2007) for a similar ripened cheese. The analysis of water activity showed an $\mathrm{a}_{\mathrm{w}}$ value of 0.93 , slightly lower than that reported by 
Table 2

Physico-chemical analysis of Manchego cheese. Data are the mean \pm standard deviation of three measurements. Different letters denote statistical differences (p $<0.05$, ANOVA).

\begin{tabular}{|c|c|c|c|}
\hline \multicolumn{2}{|c|}{ Property } & Rind & Inner \\
\hline \multicolumn{2}{|c|}{ DM (\%) } & $67.23 \pm 0.1^{\mathrm{a}}$ & $66.08 \pm 0.0^{\mathrm{b}}$ \\
\hline \multicolumn{2}{|c|}{ Fat (\%DM) } & $55.36 \pm 0.0^{\mathrm{a}}$ & $56.37 \pm 0.1^{\mathrm{b}}$ \\
\hline \multicolumn{2}{|c|}{ Proteins (\%DM) } & $36.47 \pm 0.1^{\mathrm{a}}$ & $37.68 \pm 0.0^{b}$ \\
\hline \multicolumn{2}{|c|}{ Salt $(\% \mathrm{NaCl})$} & $1.76 \pm 0.0^{\mathrm{a}}$ & $1.51 \pm 0.0^{\mathrm{b}}$ \\
\hline \multicolumn{2}{|c|}{ Moisture (\%) } & $32.78 \pm 0.1^{a}$ & $33.93 \pm 0.0^{b}$ \\
\hline \multicolumn{2}{|c|}{$\mathrm{pH}$} & n.a. & $5.04 \pm 0.0$ \\
\hline \multicolumn{2}{|c|}{ Water activity $\left(a_{w}\right)$} & n.a. & $0.93 \pm 0.0$ \\
\hline \multicolumn{2}{|c|}{ Density $\left(\mathrm{Kg} \mathrm{L}^{-1}\right)$} & n.a. & $1.09 \pm 0.1$ \\
\hline \multirow[t]{3}{*}{ Color } & $L^{*}$ & $65.24 \pm 0.6^{\mathrm{a}}$ & $81.32 \pm 1.0^{\mathrm{b}}$ \\
\hline & $a^{*}$ & $-4.21 \pm 0.3^{\mathrm{a}}$ & $-2.68 \pm 0.2^{\mathrm{b}}$ \\
\hline & $b^{*}$ & $16.31 \pm 0.3^{\mathrm{a}}$ & $12.22 \pm 0.8^{\mathrm{b}}$ \\
\hline \multirow[t]{3}{*}{$W a$} & Water & $104.23 \pm 5.3$ & n.a. \\
\hline & Glycerol & $85.72 \pm 4.4$ & n.a. \\
\hline & Bromonahptalene & $88.80 \pm 0.0$ & n.a. \\
\hline \multirow[t]{3}{*}{$W c$} & Water & $144.20 \pm 0.0$ & n.a. \\
\hline & Glycerol & $118.80 \pm 0.0$ & n.a. \\
\hline & Bromonahptalene & $88.80 \pm 0.0$ & n.a. \\
\hline \multirow[t]{3}{*}{ Ws } & Water & $-39.97 \pm 5.3$ & n.a. \\
\hline & Glycerol & $-33.02 \pm 4.4$ & n.a. \\
\hline & Bromonahptalene & $0.00 \pm 0.00$ & n.a. \\
\hline
\end{tabular}

DM: dry matter; n.a.: not assayed; Wa: work of adhesion $\left(\mathrm{mJ} \mathrm{m}^{-2}\right)$; $W c$ : work of cohesion $\left(\mathrm{mJ} \mathrm{m}^{-2}\right)$; Ws: spreading coefficient $\left(\mathrm{mJ} \mathrm{m}^{-2}\right)$.

Cabezas et al. (2007) (0.953), at the same ripening time. The color of the rind showed a darker (lower $L^{*}$ values) and greener appearance in comparison to the center mainly related to the possible contact of the rind with air. This effect was demonstrated by Licón, Carmona, Molina, and Berruga (2011), who studied changes in luminosity of a similar sheep's pressed cheese at different ageing times along 60 days and at different exposition air periods $(0,30$ and $60 \mathrm{~min})$, showing lower $L^{*}$, higher $a^{*}$, but similar $b^{*}$ cordinates with increasing air expositions and ripening times. Finally, the cheese showed a quite hydrophobic rind as deduced from the spreading coefficient values $(W s)$ of bromonaphtalene $\left(0 \mathrm{~mJ} \mathrm{~m}^{-2}\right)$ and water $\left(-40 \mathrm{~mJ} \mathrm{~m}^{-2}\right)$, which is related to its high content in fats $(55.4 \% \mathrm{DM})$. Consequently, it was necessary the addition of a surfactant (Tween 20) to the chitosan solution with the aim of decreasing the surface tension, enhancing that the solution spreads over the cheese surface (Cerqueira et al., 2009).

\subsection{Wettability, surface tension, density and $\mathrm{pH}$ of coatings}

Wettability is a very important parameter when estimating the capacity of a solution to coat a given surface. The nearer the values are to zero (Ws ??aprox. 0), the better the cheese will be covered (Cerqueira et al., 2009). As observed in Table 3, the work of adhesion and spreading coefficient did not show statistical differences $(p<0.05)$, whereas differences were obtained for the work of cohesion. Therefore, the spreading coefficient (wettability) revealed the good dispersal capacities of the newly formed coating over the cheese rind. Surface

Table 3

Physical properties of coatings. Data are the mean \pm standard deviation of three measurements. Different letters denote statistical differences $(p<0.05$, ANOVA).

\begin{tabular}{lll}
\hline Property & Control coating & SISRE coating \\
\hline Work of adhesion-Wa $\left(\mathrm{mJ} \mathrm{m}^{-2}\right)^{\mathrm{a}}$ & $57.72 \pm 2.7$ & $55.47 \pm 2.34$ \\
Work of cohesion-Wc $\left(\mathrm{mJ} \mathrm{m}^{-2}\right)^{\mathrm{a}}$ & $70.40 \pm 0.0^{\mathrm{a}}$ & $68.00 \pm 0.0^{\mathrm{b}}$ \\
Spreading coefficient $-W s\left(\mathrm{~mJ} \mathrm{~m}^{-2}\right)^{\mathrm{a}}$ & $-12.68 \pm 2.7$ & $-12.53 \pm 2.4$ \\
Surface tension $(\mathrm{mN} / \mathrm{m})$ & $34.00 \pm 0.2^{\mathrm{a}}$ & $35.20 \pm 0.6^{\mathrm{b}}$ \\
Density $\left(\mathrm{g} \mathrm{cm}^{-3}\right)$ & $1.05 \pm 0.0^{\mathrm{a}}$ & $0.98 \pm 0.0^{\mathrm{b}}$ \\
pH & $4.16 \pm 0.0^{\mathrm{a}}$ & $4.21 \pm 0.0^{\mathrm{b}}$ \\
\hline
\end{tabular}

a Over Manchego cheese rind. tension and density are significant values for cheese producers when selecting the best methods to apply the coatings over cheese rinds (e.g. spray, immersion, wrapping, etc.) (Costa et al., 2018). Table 3 shows statistical differences $(p<0.05)$ between both coatings. In the case of the surface tension, the SISRE coating presented a higher value; whereas the density of this coating was lower than that of the control and similar to that of the water $\left(1 \mathrm{~g} \mathrm{~cm}^{-3}\right)$. Likewise, Mallikarjunan, Chinnan, Balasubramaniam, and Phillips (1997) reported density values in the range of $0.84-0.97 \mathrm{~g} \mathrm{~cm}^{-3}$ for edible coatings based on hydroxypropyl methyl cellulose, corn zein and methyl cellulose. Finally, the $\mathrm{pH}$ of coatings is also significant when applying them over cheese rinds, because large differences in $\mathrm{pH}$ values might be responsible for possible acid-base reactions. As shown in Table 3, both coatings showed acid values due to the presence of lactic acid. Despite the coatings showed different $\mathrm{pH}$ values $(\mathrm{p}<0.05)$, both results are very close so such differences can be considered negligible.

\subsection{Biological capacities of coatings}

\subsubsection{Antifungal activities}

The fungistatic effects of the chitosan have been previously related to the fact that the polysaccharide interferes with the fungal uptake of minerals, especially $\mathrm{Ca}^{2+}$, and nutrients, resulting in a delay in the spore germination (Plascencia-Jatomea et al., 2003). The chitosan coatings also represent a significant barrier for the permeability of oxygen (Cerqueira et al., 2010), that in addition to the low temperature during the ripening of the cheese probably reduce the development of fungi. On the basis of the antifungal capacities observed for the SISRE (Ortiz de Elguea-Culebras, 2017a), its inclusion into a chitosan-based coating could further impair the development of the most frequent fungi in Manchego cheese rinds (Serrano-Martinez, 1997). Accordingly, the SISRE coating showed in general better in vitro antifungal capacities than the control coating against all assayed molds (Fig. 1). The behavior is more similar between A. flavus and P. verrucosum than between the two species of Penicillium, although in the case of A. flavus the inhibition in the control never completely disappears as for $P$. verrucosum. The SISRE coating reduced the growth of $A$. flavus in more than $50 \%$ after 3 days of incubation in comparison with the control, although this inhibition decreased along time (56.0-13.1\%) suggesting that the SISRE was especially active during the first stages of the development of this mold. In contrast, the SISRE coating initially showed a minor inhibition of $P$. roqueforti in relation to the control coating but after 5 days of incubation the inhibition improved up to reach around $20 \%$ at the end of the incubation. Finally, $P$. verrucosum was the mold most affected by the SISRE coating throughout the incubation presenting inhibition values from $67.7 \%$ ( 3 days) to $26.5 \%$ (7 days), whilst the control showed almost no inhibition after 4 days of incubation. Ortiz de ElgueaCulebras (2017a) previously observed similar trends for the SISRE acting alone on A. flavus and $P$. roqueforti, whereas a higher effect seemed to be observed on $P$. verrucosum. Sabaghi, Maghsoudlou, Khomeiri, and Ziaiifar (2015) and Georgantelis, Ambrosiadis, Katikou, Blekas, and Georgakis (2007) also demonstrated an enhancing effect on the antifungal capacities of chitosan coatings containing extracts of green tea and rosemary, respectively.

\subsubsection{Antioxidant capacities}

The notorious presence of antioxidant compounds (phenols) in the SISRE coating (10.1 equivalent $\mathrm{g}$ of gallic acid/100 $\mathrm{g}$ ), including as the most important phenols the salvianolic acid A (80.5\%), the quercetin-3O-rutinoside (1.7\%) and the feruloyl-5-caffeoylquinic acid (1.5\%), as previously reported in Gonzalo Ortiz de Elguea-Culebras et al., 2017b; may well improve the stability of lipids and proteins present in cheese rinds, especially important in fatty cheeses such as the Manchego. The SISRE coating showed an $I C_{50}$ of $31.52 \pm 0.5 \mu \mathrm{g} \mathrm{mL}^{-1}$ in the DPPH radical-scavenging test, whereas no activity was observed for the chitosan as previously reported in Xie, Xu, and Liu (2001). 


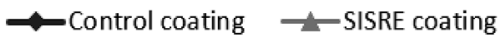

A

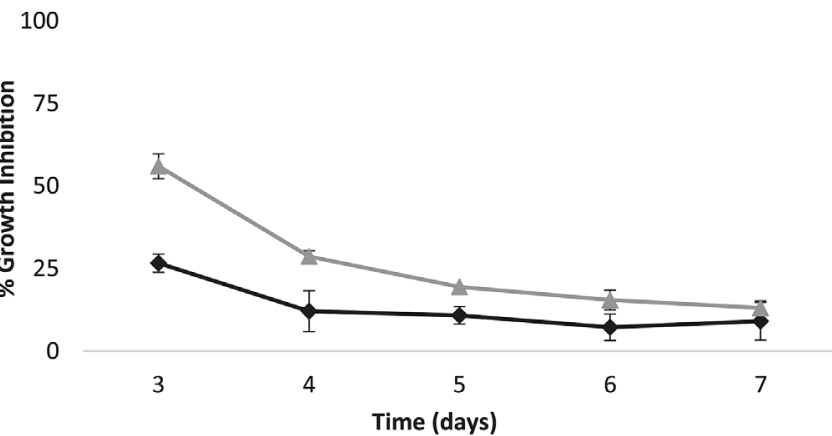

B

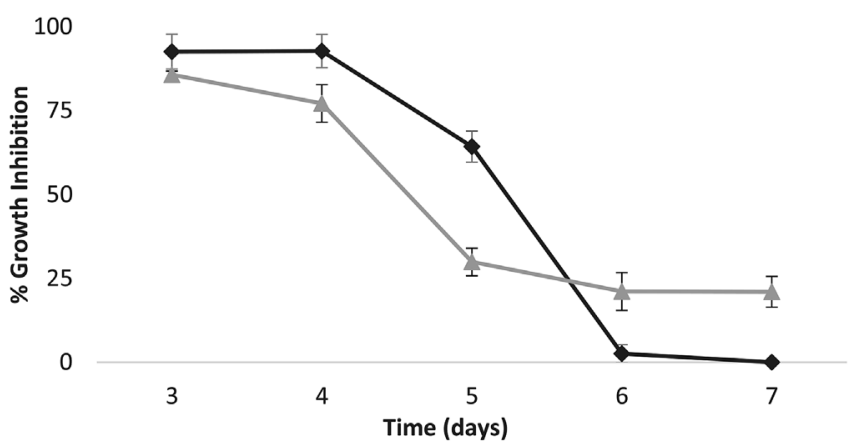

C

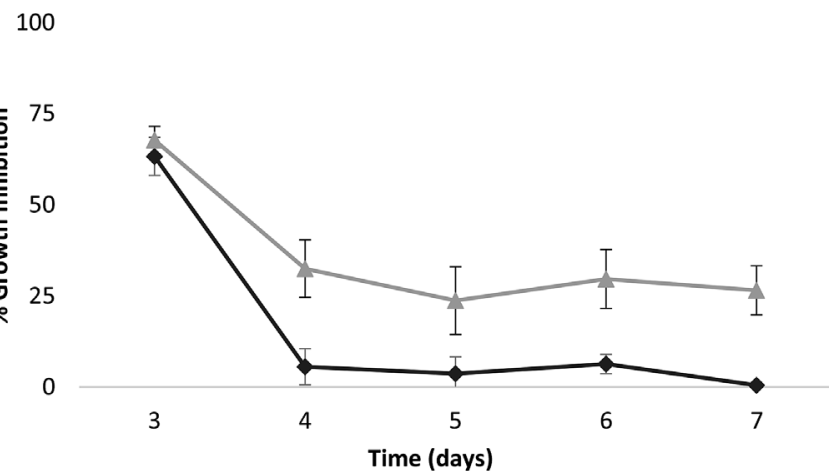

Fig. 1. Antifungal capacities of control and SISRE coatings against: A. Aspergillus flavus, B. Penicillium roqueforti and C. Penicillium verrucosum. Data are the mean \pm standard deviation of three measurements and are expressed as the growth inhibition with respect to the control (PDA).

The linoleic acid model system test also showed that the incorporation of SISRE notoriously improved the antioxidant capacity of the coating. As observed (Fig. 2), the linoleic acid was almost completely oxidized after $24 \mathrm{~h}$ of incubation with the control coating as deduced from the extensive generation ( $>75 \%$ ) of conjugated dienes, lipid hydroperoxides and carbonyl groups. In contrast, the SISRE coating prevented the formation of conjugated dienes throughout the incubation and reduced the presence of lipid hydroperoxides (60-66\% less) and carbonyl groups (30-43\%) with respect to the control coating. These results are consistent with the antioxidant capacity previously observed for the SISRE, especially in the reduced formation (50\% less) of conjugated dienes (Ortiz de Elguea-Culebras et al., 2017b). Similarly, Ponce et al. (2008) also observed a minor formation of peroxides in chitosan coatings containing 7 different oleoresin extracts.
A

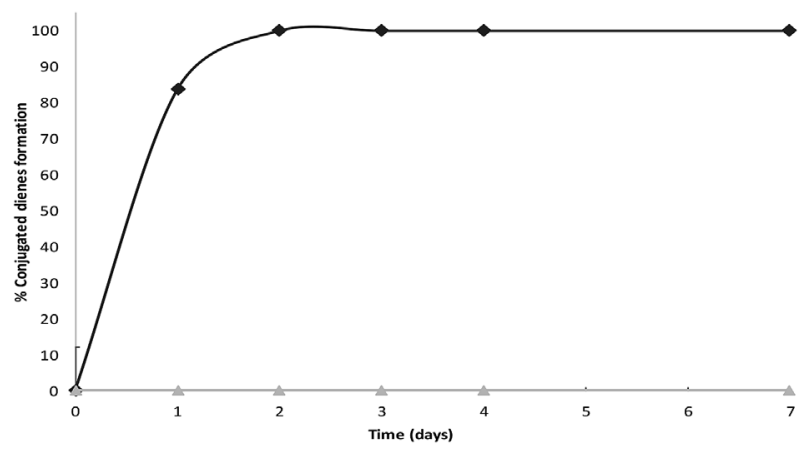

B

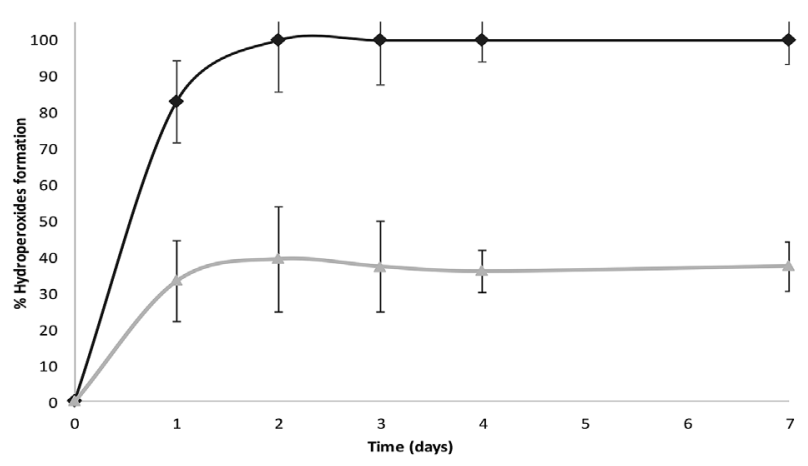

C

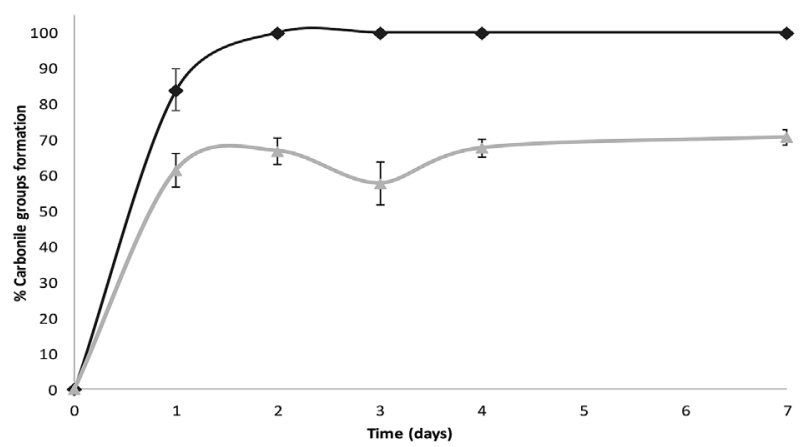

Fig. 2. Formation of oxidation compounds: A. conjugated dienes, B. lipid hydroperoxides and C. carbonyl groups during the incubation of linoleic acid with control and SISRE coatings. Data are the mean \pm standard deviation of three incubations and are expressed as the percentage of formation with respect to a negative control ( $100 \%$ oxidation) of distilled water.

\subsection{Films properties}

\subsubsection{Moisture}

The analysis of moisture content is of significance since high contents enhances a better adhesion of film on aqueous food products, whereas films with low contents are more suitable for fatty foods (Cozmuta et al., 2015). As observed (Table 4), the SISRE film yielded lower content of moisture $(20.15 \%)$ than the control $(27.25 \%)$. This could be explained by the fact that the control is made up of compounds highly soluble in water probably with a major capacity to retain water than the SISRE film that also includes in its composition certain hydrophobic compounds (e.g. lipids, pigments) with a lesser affinity for water molecules. A similar effect with close results to that in our study was observed by Costa et al. (2015) for a 1.5\% chitosan film containing a sample of wheat bran arabinoxylan extract $(0.2 \%)$, which showed lower moisture content than the control film. Likewise, Souza et al. (2017) reported a similar moisture content for chitosan films (1.5\%) 
Table 4

Analytical properties of the different assayed films. Data are the mean \pm standard deviation of three measurements. Different letters denote statistical differences among films ( $\mathrm{p}<0.05$, ANOVA).

\begin{tabular}{|c|c|c|c|}
\hline \multicolumn{2}{|l|}{ Property } & Control film & SISRE film \\
\hline \multicolumn{2}{|l|}{ Moisture (\%) } & $27.25 \pm 1.6^{\mathrm{a}}$ & $20.15 \pm 1.0^{\mathrm{b}}$ \\
\hline \multicolumn{2}{|l|}{ Solubility (\%) } & $49.27 \pm 2.0^{\mathrm{a}}$ & $32.82 \pm 1.1^{\mathrm{b}}$ \\
\hline \multicolumn{2}{|l|}{ Swelling (\%) } & n.d. & $435.44 \pm 24.7$ \\
\hline \multirow[t]{5}{*}{ Color } & $L^{*}$ & $94.41 \pm 0.9^{\mathrm{a}}$ & $46.23 \pm 4.5^{\mathrm{b}}$ \\
\hline & $a^{*}$ & $-2.25 \pm 0.4^{\mathrm{a}}$ & $20.08 \pm 1.8^{\mathrm{b}}$ \\
\hline & $b^{*}$ & $14.05 \pm 3.0^{\mathrm{a}}$ & $41.66 \pm 5.1^{\mathrm{b}}$ \\
\hline & $C^{*}$ & $14.23 \pm 3.0^{\mathrm{a}}$ & $46.33 \pm 4.6^{b}$ \\
\hline & Hue angle $(\stackrel{\circ}{)}$ & $99.17 \pm 0.7^{\mathrm{a}}$ & $63.94 \pm 3.7^{\mathrm{b}}$ \\
\hline \multicolumn{2}{|l|}{ Opacity (\%) } & $5.25 \pm 0.6^{\mathrm{a}}$ & $23.67 \pm 5.5^{\mathrm{b}}$ \\
\hline \multicolumn{2}{|l|}{ Thickness (mm) } & $0.08 \pm 0.0^{\mathrm{a}}$ & $0.16 \pm 0.0^{\mathrm{b}}$ \\
\hline \multirow[t]{2}{*}{ Mechanical properties } & $\begin{array}{l}\text { Tensile strength-TS } \\
\text { (MPa) }\end{array}$ & $9.57 \pm 1.7^{\mathrm{a}}$ & $3.12 \pm 0.0^{\mathrm{b}}$ \\
\hline & $\begin{array}{l}\text { Elongation at } \\
\text { break-EAB (\%) }\end{array}$ & $86.07 \pm 13.9^{\mathrm{a}}$ & $101.16 \pm 6.4^{b}$ \\
\hline \multirow[t]{2}{*}{ Thermal properties } & $\begin{array}{l}\text { Melting } \\
\text { temperature- } T_{m} \\
\left({ }^{\circ} \mathrm{C}\right)\end{array}$ & $150.11 \pm 1.0$ & $148.46 \pm 0.1$ \\
\hline & $\begin{array}{l}\text { Specific enthalpy- } \\
\Delta h_{m}\left(\mathrm{~J} \mathrm{~g}^{-1}\right)\end{array}$ & $281.25 \pm 52.1$ & $211.88 \pm 27.9$ \\
\hline \multicolumn{2}{|c|}{ WVP $\times 10^{-10}\left(\mathrm{~g} \cdot(\mathrm{m} \cdot \mathrm{s} \cdot \mathrm{Pa})^{-1}\right)$} & $0.87 \pm 0.6$ & $1.36 \pm 0.0$ \\
\hline \multirow[t]{3}{*}{$\begin{array}{l}\text { Surface tension of } \\
\quad \text { films }\left(\mathrm{mJ} \mathrm{m}^{-2}\right)\end{array}$} & $\begin{array}{l}\text { Work of adhesion- } \\
W a\end{array}$ & $113.17 \pm 7.0^{\mathrm{a}}$ & $128.60 \pm 1.5^{\mathrm{b}}$ \\
\hline & $\begin{array}{l}\text { Work of cohesion- } \\
W c\end{array}$ & $144.20 \pm 0.0$ & $144.20 \pm 0.0$ \\
\hline & $\begin{array}{l}\text { Spreading } \\
\text { coefficient-Ws }\end{array}$ & $-31.03 \pm 7.0^{\mathrm{a}}$ & $-15.60 \pm 1.5^{\mathrm{b}}$ \\
\hline
\end{tabular}

n.d.: not detected.

containing $1 \%$ of hydro-alcoholic extracts of ginger green tea and kenaf (Table 4). However, these authors reported higher moisture for chitosan films containing the extract than for the control.

\subsubsection{Solubility}

Film solubility is also important as high soluble films are less resistant to water and facilitates the transference of bioactive compounds into the food (Casariego et al., 2009). Solubility tests showed that the incorporation of the SISRE reduces the solubility of dry films in water probably because, as in the case of moisture, some compounds of the extract renders the film more hydrophobic (Table 4). The decrease in solubility capacities was also observed by Souza et al. (2017) for a hydro-alcoholic chitosan-green tea extract film, although opposite effects were also observed for chitosan films added with similar extracts of rosemary, ginger, sage, black tea and kenaf.

\subsubsection{Swelling index}

The swelling index evaluates the water binding ability of a film. A high swelling index results in high water retention capacities and good moisture barrier properties, whereas a film with a low swelling may dissolve during contact with aqueous products (Cozmuta et al., 2015). It was observed (Table 4) that the addition of the SISRE improved considerably the capacity of the film to absorb water (435\%), while the control that was totally dissolved in water during the assay. This suggests that some compounds of the SISRE interact with the chitosan matrix avoiding the solubility of the film but, at the same time, they facilitate the absorption of water molecules. Anyway, it should be noted that a good balance between solubility and swelling is very important in cheeses as films presenting a high solubility can be degraded during the processing and storage of the cheese but an excessive absorption of water might create a barrier that impair the water loss during ripening.

\subsubsection{Color, opacity and transparency}

The first characteristic that makes a consumer to acquire a new product is the visual aspect, so the study of the appearance should be performed. The color of the SISRE film was different in comparison to the control. However, this color does not differ from the also brownish color developed in natural rinds of Manchego cheeses after several ripening months. As observed in Table 4, the luminosity $\left(L^{*}\right)$ of the film after the addition of the SISRE film decreased significantly, being remarkable the considerable decrease in brightness. Besides, the $a^{*}$ and $b^{*}$ values were also very different between films $(p<0.05)$ as result of the characteristic brown color imparted by the SISRE to the film. Siripatrawan and Harte (2010) also observed a decrease in luminosity and an increase in the $a^{*}$ and $b^{*}$ values by increasing the amount of an aqueous green tea extract to a chitosan-based film. Chroma $\left(C^{*}\right)$ and hue angle are, together with luminosity, the most important psychophysical color characteristics. As observed, the SISRE film presented a more saturated color (higher chroma) and a lower hue angle in comparison to the control film. Similarly, Souza et al. (2017) recently reported an increase of the $C^{*}$ value and a decrease of the hue angle when a $1.5 \%$ chitosan film control was added with rosemary, sage, green tea and kenaf hydro-alcoholic extracts.

The study of the opacity and transparency of films is also important as high opacities or low transparencies may well avoid possible photooxidation effects, once light catalyzes such reactions responsible for food deterioration. This generally occurs in the UV region $(10-400 \mathrm{~nm})$ and, according to Souza et al. (2017), the ability of reducing the UV light transparency in food packaging is advantageous to extend the shelf life of products as cheeses (Kastrup-Dalsgaard et al., 2010). The incorporation of the extract to the film increased its opacity considerably (Table 4), which is also consistent with a significant reduction in the transparency of light in the UV-visible range (Fig. 3). This increase in the opacity was also observed by Gómez-Estaca, Giménez, Montero, and Gómez-Guillén (2009) as a result of the addition of natural antioxidants from borage extracts into edible fish gelatin films. The transparency of the SISRE film at wavelengths below $400 \mathrm{~nm}$ were lower than $1 \%$, whereas for the control the UV light transmittances ranged from $0.3 \%(200 \mathrm{~nm})$ to $55.8 \%(400 \mathrm{~nm})$. Such effect is attributed to the opacity of the SISRE film but could also be partially due to the capacity of phenols to absorb UV light.

\subsubsection{Film thickness}

The addition of the SISRE increased the thickness of the chitosan films in $0.08 \mathrm{~mm}$ average (Table 4). This is in agreement with Shahbazi (2017) who observed an increase in thickness with the addition of an ethanolic grape seed extract into a chitosan matrix, but in contradiction to Souza et al. (2017) who observed a decrease in film thickness by the addition of different hydro-alcoholic extracts to the same polysaccharide. This increase could be related to the formation of protruded structures by the different chemical compounds contained in the SISRE with the chitosan, as proposed by Shahbazi (2017).

\subsubsection{Mechanical properties}

Siripatrawan and Harte (2010) studied the mechanical properties of a chitosan film added with different percentages of glycerol, observing that at a concentration of $30 \%$ (w/w chitosan), the mechanical properties were optimal. The addition of the SISRE reduced the tensile strength (TS) but increased the elongation-at-break (EAB) parameter resulting in a weaker but more elastic film as compared to the control film (Table 4). This increase of EAB and decrease of TS was also observed during the addition of different bioactive compounds (whey protein, glycomacropeptide and lactoferrin) to chitosan-based films (Bourbon et al. (2011). Nevertheless, Siripatrawan and Harte (2010) showed no statistical differences in TS and EAB values between a $2 \%$ green tea-chitosan film and its control. Kalaycıŏlu et al. (2017) reviewed the influence of additives on TS of films and, although the mechanism underlying the differences observed remains unclear, it seems evident that the intermolecular interactions between the additives and the chitosan chains play a major role. Such differences could be related in our case to interactions by H-bonds between the hydroxyl groups of phenols and the $-\mathrm{NH}_{2}$ of chitosan (Kanatt, Chander, \& 


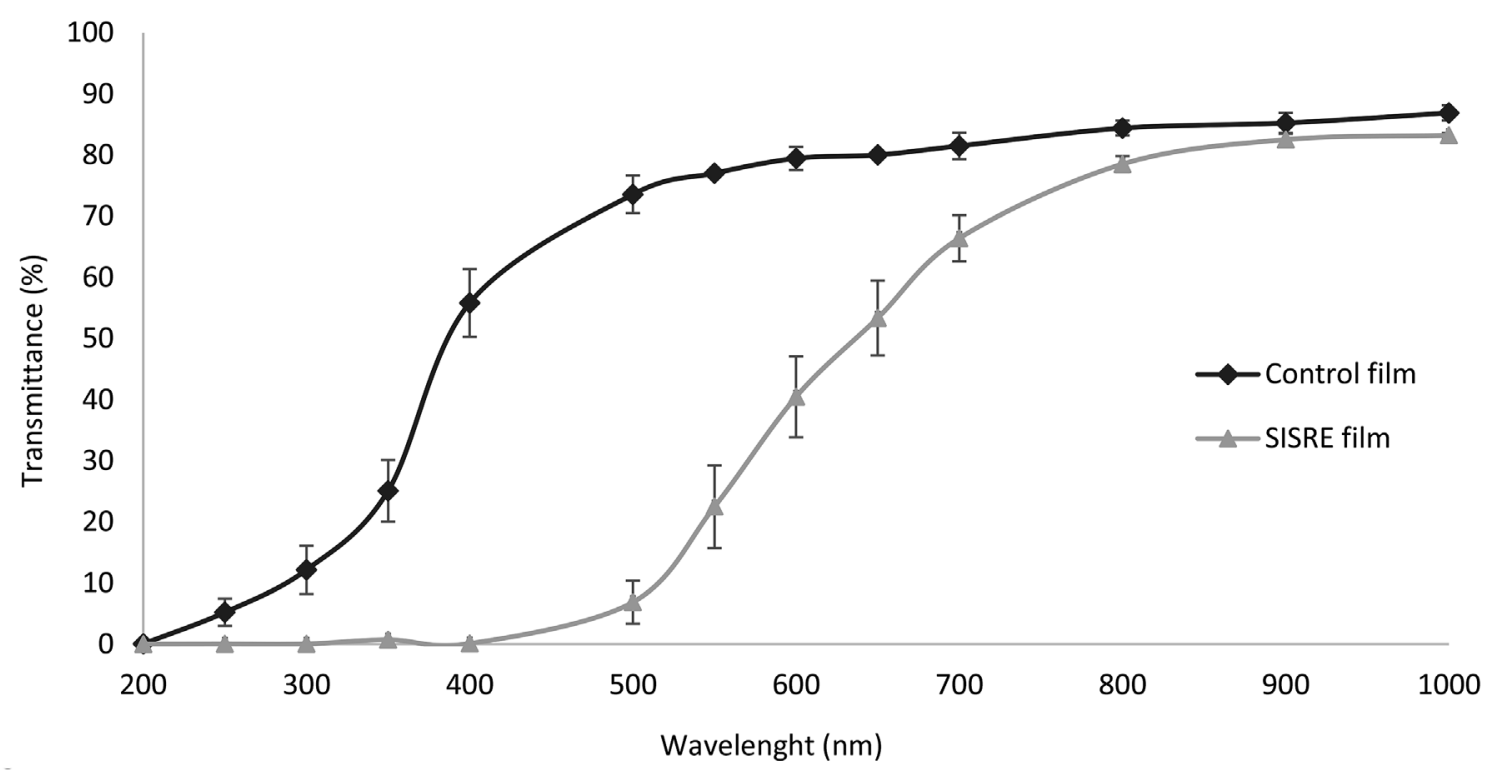

Fig. 3. UV-visible transparency (\% transmittance) of control and SISRE film. Data are the mean \pm standard deviation of three measurements.

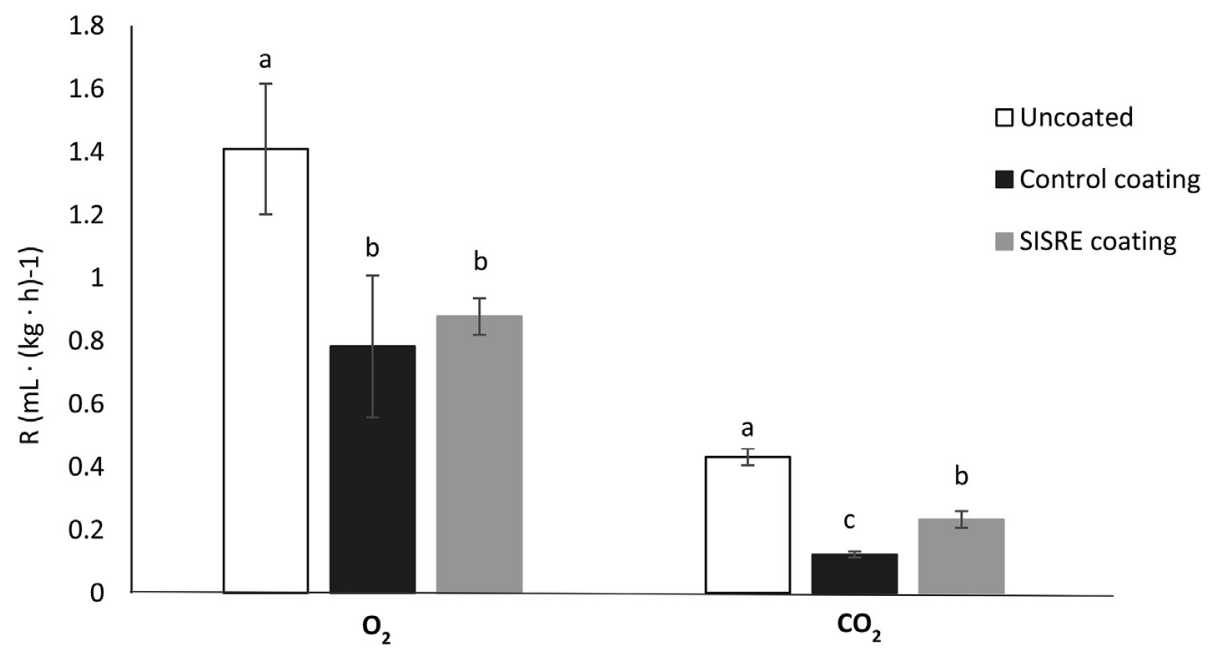

Fig. 4. $\mathrm{O}_{2}$ and $\mathrm{CO}_{2}$ transfer rates in Manchego cheese. Data are the mean \pm standard deviation of three measurements. Different letters denote statistical differences among samples $(\mathrm{p}<0.05$, ANOVA).

Sharma, 2008; Li, Miao, Wu, Chen, \& Zhang, 2014; Shahbazi, 2017).

\subsubsection{Thermal properties}

According to Bourbon et al. (2011), an increase in crystallinity results in more breakable (lower TS) and elastic (higher EAB) films. These authors observed such effect by monitoring the TS and EAB properties during the addition of high molecular compounds to a chitosan film. However, there were no significant differences in the thermal properties between the SISRE and control films (Table 4), so the differences observed in TS and EAB could be due to an uneven dispersion of the SISRE into the film as suggested by Li et al. (2014). These authors demonstrated by means of scanning electron microscopy images that the addition of vegetal extracts to gelatin-based films induce the development of heterogeneous structures with presence of discontinuous areas, leading to lower tensile strengths.

\subsubsection{Water vapor permeability (WVP)}

WVP is directly related to the capacity of water to permeate through the films, so low WVP values improve the structural integrity and mechanical-handling properties of the coated product (Galus \& Kadzińska, 2015), but may reduce water loss (Cerqueira et al., 2010), thus delaying the ripening of hard and semi-hard cheeses such as the Manchego. Results showed that the water vapor permeability of the SISRE film $(1.36 \mathrm{~g}$ $\left.\mathrm{x}(\mathrm{m} \mathrm{x} \mathrm{s} \mathrm{x} \mathrm{Pa})^{-1}\right)$ increased in comparison to that of the control film $\left(0.87 \mathrm{~g} \mathrm{x}\left(\mathrm{m} \mathrm{x} \mathrm{s} \mathrm{x} \mathrm{Pa}^{-1}\right)\right.$ (Table 4). This is consistent with the results of Kalaycıoglu et al. (2017), who observed an increment in the WVP for a chitosan film containing an ethanolic turmeric extract in comparison to the control, and with Bonilla and Sobral (2016) who studied the effect of the addition of different rosemary extracts on the WVP of a pigskin gelatin film.

\subsubsection{Surface tension of films}

The addition of the SISRE to the film made it much more hydrophilic, as deduced by the spreading coefficient of water over the SISRE film $\left(-15.60 \mathrm{~mJ} \mathrm{~m}^{-2}\right)$ in comparison to the control $\left(-31.03 \mathrm{~mJ} \mathrm{~m}^{-2}\right)$, which might also be responsible for the increase in the WVP (Souza et al., 2009). This could also explain the higher swelling capacities of the SISRE film.

\subsection{Oxygen and carbon dioxide exchange rates}

According to Siripatrawan and Harte (2010) and Sabaghi et al. 


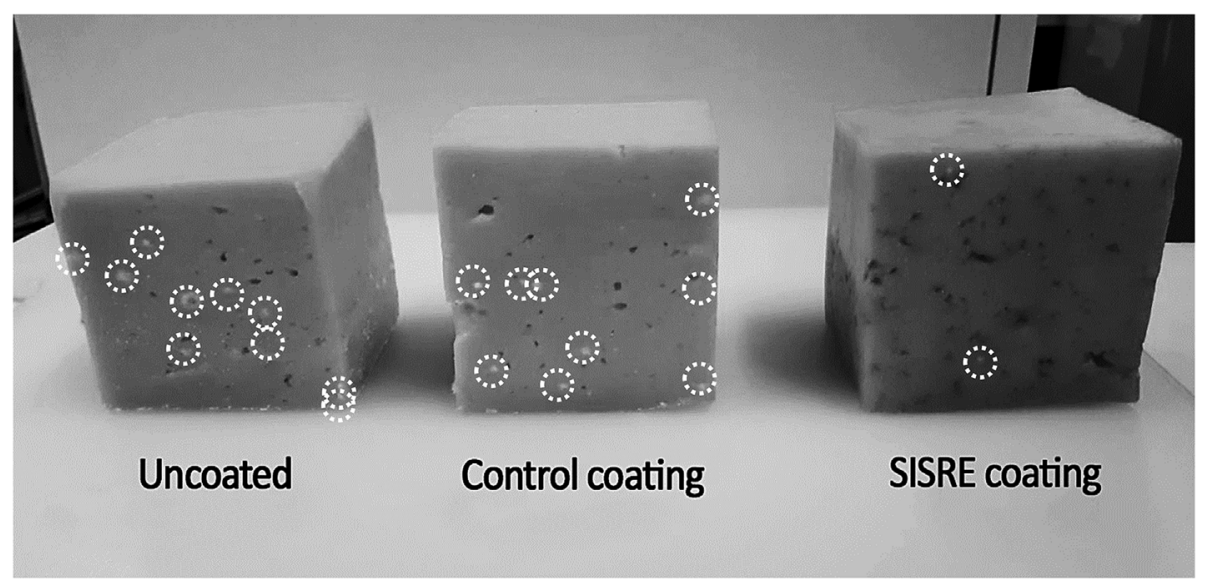

Fig. 5. Visual aspect of cheese cubes after 15 days of incubation, including growth fungal colonies.

(2015), the addition of extracts in a coating reinforces the oxygen barrier thus enhancing the antimicrobial capacity. Besides, a lower permeation of oxygen into coated cheeses is related with a better reduction of potential oxidation processes. As shown in Fig. 4, the respiration rate of oxygen was similar $(p<0.05)$ in the control $(0.8 \mathrm{~mL}$. $\left.(\mathrm{kg} \cdot \mathrm{h})^{-1}\right)$ and the SISRE coatings $\left(0.9 \mathrm{~mL} \cdot(\mathrm{kg} \cdot \mathrm{h})^{-1}\right)$ but different in the uncoated cheese $\left(1.4 \mathrm{~mL} \cdot(\mathrm{kg} \cdot \mathrm{h})^{-1}\right)$. In relation to carbon dioxide, differences were observed among the control $\left(0.1 \mathrm{~mL} \cdot(\mathrm{kg} \cdot \mathrm{h})^{-1}\right)$, the SISRE coating $\left(0.2 \mathrm{~mL} \cdot(\mathrm{kg} \cdot \mathrm{h})^{-1}\right)$ and the uncoated cheese $(0.4 \mathrm{~mL}$. $\left.(\mathrm{kg} \cdot \mathrm{h})^{-1}\right)$. This fact may be attributed to the increase in the permeability of the SISRE film (WVP) in comparison to the control film and to internal chemical reactions inside the cheese. Other studies based on the analysis of respiration rates of edible chitosan coatings with essential oils of Rosmarinus officinalis and Origanum vulgare showed $\mathrm{O}_{2}$ consumption values between $0.4 \mathrm{~mL} \cdot(\mathrm{kg} \cdot \mathrm{h})^{-1}$ for a chitosan-oregano oil coating to $5.3 \mathrm{~mL} \cdot(\mathrm{kg} \cdot \mathrm{h})^{-1}$ for the uncoated cheese, after 15 days of ripening (Cano-Embuena et al., 2017; Cerqueira et al., 2009). In the same line, these authors reported a production of $\mathrm{CO}_{2}$ between $1.1 \mathrm{~mL}$. $(\mathrm{kg} \cdot \mathrm{h})^{-1}$ for the same a chitosan-oregano oil coating to $5.6 \mathrm{~mL} \cdot(\mathrm{kg} \cdot$ h) ${ }^{-1}$ for the uncoated cheese, after 30 days of ripening. Finally, Cerqueira et al. (2009) also studied the gas exchange ratios of a recently pressed semi-hard Saloio cheese covered with a $1.5 \%$ galactomannan coating, showing a higher $\mathrm{O}_{2}$ consumption ratio of $13.7 \mathrm{~mL} \cdot(\mathrm{kg} \cdot \mathrm{h})^{-1}$ for the uncoated and of $8.3 \mathrm{~mL} \cdot(\mathrm{kg} \cdot \mathrm{h})^{-1}$ for the coated cheese. Additionally, the $\mathrm{CO}_{2}$ production of the coated cheese was of $9.3 \mathrm{~mL} \cdot(\mathrm{kg} \cdot$ h) ${ }^{-1}$ and of $14.5 \mathrm{~mL} \cdot(\mathrm{kg} \cdot \mathrm{h})^{-1}$ for the uncoated cheese. These variances can be related to the dissimilar composition of the cheese at different ripening stages (Cano-Embuena et al., 2017; Cerqueira et al., 2009).

Regarding the weight loss, the uncoated, and the cheeses coated with the control and the SISRE showed a loss of 2.5, 2.1 and 2.6\%, respectively (data not shown). Therefore, a similar weight loss of water was observed for the cheese coated with SISRE coating and the uncoated one, suggesting that the ripening process is not affected by the coating, however, long-term studies are necessary to verify such affirmation.

\subsection{Visual aspect of cheeses after incubation}

As observed in Fig. 5, the most affected cheese was the uncoated sample, followed by the control, whereas the less contaminated was the one coated with SISRE coating, which showed just a few fungal colonies, confirming the results observed in the in vitro antifungal tests. Sabaghi et al. (2015) also observed higher populations of yeasts and molds for uncoated fresh walnut kernel than those coated with chitosan coatings incorporated with green tea extract after 6 weeks of incubation. Likewise, Georgantelis et al. (2007) showed a decrease of yeast/ molds colonies on sausages coated with a chitosan coating containing a rosemary extract in comparison to the control along 20 days of incubation.

\section{Conclusions}

The use of an optimized chitosan solution containing glycerol and Tween 20 has resulted in an excellent vehicle for the incorporation of an industrial solid residue extract of $S$. chamaecyparissus in a coating for the preservation of Manchego cheese. This incorporation yielded a coating with enhanced antifungal and antioxidant capacities with respect to the original chitosan coating. Moreover, the physical properties of films showed that moisture, solubility, TS, Ws and transparency values were reduced when the SISRE was incorporated, whereas swelling, opacity, thickness, EAB and WVP increased. Finally, the consumption of $\mathrm{O}_{2}$ was similar to that of the control coating, whereas the production of $\mathrm{CO}_{2}$ was higher; however, both coatings showed noticeably lower gas exchange than the uncoated cheese. In conclusion, the use of Santolina chamaecyparissus by-product has resulted in a prospective preservation system for its application as a coating for Manchego cheeses or other similar fatty ones. In addition, this represents a novel strategy for the valorization of Santolina chamaecyparissus by-products.

\section{Acknowledgments}

This research has been financially supported by the Instituto Nacional de Investigaciones Agrarias (INIA, http://inia.es) by the project RTA2015-00018-C03-02 and RTA2013-00005-00-00. Gonzalo Ortiz de Elguea-Culebras thanks to the Consejería de Educación, Cultura y Deportes (Junta de Comunidades de Castilla-La Mancha) and the European Social Fund (FSE) for additional funding. Ana I. Bourbon and António A. Vicente thank the Portuguese Foundation for Science and Technology (FCT) by strategic funding of UID/BIO/04469/2013 unit and COMPETE 2020 (POCI-01-0145-FEDER-006684) and BioTecNorte operation (NORTE-01-0145-FEDER-000004) funded by the European Regional Development Fund under the scope of Norte2020 - Programa Operacional Regional do Norte. Manuel Carmona also thanks to the Spanish Ministry of Science, Innovation and Universities for the Ramón y Cajal Fellowships RyC-2014-16307. We are very grateful to Paula Pereira and Eduardo Gudiña for their assistance and technical support.

\section{References}

ASTM D882-10 (2010). Standard test method for tensile properties of thin plastic sheeting West Conshohocken, PA: ASTM International. Retrieved from www.astm.org.

ASTM E96/E96M-16 (2016). Standard test methods for water vapor transmission of materials. West Conshohocken, PA: ASTM International. Retrieved from www.astm.org. 
Bonilla, J., \& Sobral, P. J. A. (2016). Investigation of the physicochemical, antimicrobial and antioxidant properties of gelatin-chitosan edible film mixed with plant ethanolic extracts. Food Bioscience, 16, 17-25. https://doi.org/10.1016/j.fbio.2016.07.003.

Bourbon, A. I., Pinheiro, A. C., Cerqueira, M. A., Rocha, C. M. R., Avides, M. C., Quintas, M. A. C., et al. (2011). Physico-chemical characterization of chitosan-based edible films incorporating bioactive compounds of different molecular weight. Journal of Food Engineering, 106(2), 111-118. https://doi.org/10.1016/j.jfoodeng.2011.03.024.

Cabezas, L., Sánchez, I., Poveda, J. M., Seseña, S., \& Palop, M. L. (2007). Comparison of microflora, chemical and sensory characteristics of artisanal Manchego cheeses from two dairies. Food Control, 18(1), 11-17. https://doi.org/10.1016/j.foodcont.2005.07. 010 .

Cano-Embuena, A. I., Cháfer-Nácher, M., Chiralt-Boix, A., Molina-Pons, M. P., BorrásLlopis, M., Beltran-Martínez, M. C., et al. (2017). Quality of goat's milk cheese as affected by coating with edible chitosan-essential oil films. International Journal of Dairy Technology, 70(1), 68-76. https://doi.org/10.1111/1471-0307.12306.

Casariego, A., Souza, B. W. S., Cerqueira, M. A., Teixeira, J. A., Cruz, L., Díaz, R., et al. (2009). Chitosan/clay films' properties as affected by biopolymer and clay micro/ nanoparticles' concentrations. Food Hydrocolloids, 23(7), 1895-1902. https://doi.org/ 10.1016/j.foodhyd.2009.02.007.

Cerqueira, M. A., Lima, Á. M., Souza, B. W. S., Teixeira, J. A., Moreira, R. A., \& Vicente, A. A. (2009). Functional polysaccharides as edible coatings for cheese. Journal of Agricultural and Food Chemistry, 57(4), 1456-1462. https://doi.org/10.1021/ jf802726d.

Cerqueira, M. A., Sousa-Gallagher, M. J., Macedo, I., Rodriguez-Aguilera, R., Souza, B. W. S., Teixeira, J. A., et al. (2010). Use of galactomannan edible coating application and storage temperature for prolonging shelf-life of "Regional" cheese. Journal of Food Engineering 97(1), 87-94. https://doi.org/10.1016/j.jfoodeng 2009.09.019.

Costa, M. J., Cerqueira, M. A., Ruiz, H. A., Fougnies, C., Richel, A., Vicente, A. A., et al. (2015). Use of wheat bran arabinoxylans in chitosan-based films: Effect on physicochemical properties. Industrial Crops and Products, 66, 3050311. https://doi.org/ 10.1016/j.indcrop.2015.01.003.

Costa, M. J., Maciel, L. C., Teixeira, J. A., Vicente, A. A., \& Cerqueira, M. A. (2018). Use of edible films and coatings in cheese preservation: Opportunities and challenges. Food Research International, 107, 84-92. November 2017 https://doi.org/10.1016/j. foodres.2018.02.013.

Cozmuta, A. M., Turila, A., Apjok, R., Ciocian, A., Mihaly Cozmuta, L., Peter, A., et al. (2015). Preparation and characterization of improved gelatin films incorporating hemp and sage oils. Food Hydrocolloids, 49, 144-155. https://doi.org/10.1016/j. foodhyd.2015.03.022.

Džamić, A. M., Soković, M. D., Novaković, M., Jadranin, M., Ristić, M. S., Tešević, V., et al. (2013). Composition, antifungal and antioxidant properties of Hyssopus officinalis L. subsp. pilifer (Pant.) Murb. essential oil and deodorized extracts. Industrial Crops and Products, 51, 401-407. https://doi.org/10.1016/j.indcrop.2013.09.038.

European Parliament and Council (2012). Regulation (EC) No 129/2012 of the European Parliament and of the Council of 13 February 2012 approving minor amendments to the specification for a name entered in the register of protected designations of origin and protected geographical indications. Official Journal of the European Union. Retrieved from https://eur-lex europa.eu/legal-content/ES/TXT/?ur.

European Parliament and Council (2017). Regulation (EC) No 2017/2470 of the European parliament and of the council of 20 December 2017 establishing the union list of novel foods in accordance with regulation (EU) 2015/2283 of the European parliament and of the council on novel foods. Official Journal of the European Union. Retrieved from https://eur-lex.europa.eu/legal-content/en/TXT/?uri= CELEX:32017R2470.

FDA (2002). Agency response letter GRAS Notice No. GRN 000073. U.S. Food and drug Administration. Retrieved from https://www.accessdata.fda.gov/scripts/fdcc/?set GRASNotices\&id $=73 \&$ sort $=$ GRN_No\&order $=$ DESC\&startrow $=1 \&$ type $=$ basic\& search $=$ chitosan

Galus, S., \& Kadzińska, J. (2015). Food applications of emulsion-based edible films and coatings. Trends in Food Science \& Technology, 45(2), 273-283. https://doi.org/10. 1016/j.tifs.2015.07.011.

Georgantelis, D., Ambrosiadis, I., Katikou, P., Blekas, G., \& Georgakis, S. A. (2007). Effect of rosemary extract, chitosan and $\alpha$-tocopherol on microbiological parameters and lipid oxidation of fresh pork sausages stored at $4^{\circ} \mathrm{C}$. Meat Science, 76(1), 172-181. https://doi.org/https://doi.org/10.1016/j.meatsci.2006.10.026.

Gómez-Estaca, J., Giménez, B., Montero, P., \& Gómez-Guillén, M. C. (2009) Incorporation of antioxidant borage extract into edible films based on sole skin gelatin or a commercial fish gelatin. Journal of Food Engineering, 92(1), 78-85. https: doi.org/10.1016/j.jfoodeng.2008.10.024.

Gudiña, E. J., Rodrigues, A. I., de Freitas, V., Azevedo, Z., Teixeira, J. A., \& Rodrigues, L. R. (2016). Valorization of agro-industrial wastes towards the production of rhamnolipids. Bioresource Technology, 212, 144-150. https://doi.org/10.1016/j.biortech. 2016.04 .027$.

Hymery, N., Vasseur, V., Coton, M., Mounier, J., Jany, J.-L., Barbier, G., et al. (2014). Filamentous fungi and mycotoxins in cheese: A review. Comprehensive Reviews in Food Science and Food Safety, 13(4), 437-456. https://doi.org/10.1111/1541-4337.12069.

Jeršek, B., Poklar Ulrih, N., Skrt, M., Gavarić, N., Božin, B., \& Smole Možina, S. (2014). Effects of selected essential oils on the growth and production of ochratoxin A by Penicillium verrucosum. Archives of Industrial Hygiene and Toxicology, 65(2), 65. https://doi.org/10.2478/10004-1254-65-2014-2486.

Kalaycıŏlu, Z., Torlak, E., Akın-Evingür, G., Özen, İ., \& Erim, F. B. (2017). Antimicrobial and physical properties of chitosan films incorporated with turmeric extract. International Journal of Biological Macromolecules, 101, 882-888. https://doi.org/10. 1016/j.ijbiomac.2017.03.174.

Kanatt, S. R., Chander, R., \& Sharma, A. (2008). Chitosan and mint mixture: A new preservative for meat and meat products. Food Chemistry, 107(2), 845-852. https:// doi.org/https://doi.org/10.1016/j.foodchem.2007.08.088

Kastrup-Dalsgaard, T., Sørensen, J., Bakman, M., Vognsen, L., Nebel, C., Albrechtsen, R., et al. (2010). Light-induced protein and lipid oxidation in cheese: Dependence on fat content and packaging conditions. Dairy Science \& Technology, 90(5), 565-577. https://doi.org/10.1051/dst/2010019.

Licón, C. C., Carmona, C. B., Molina, A. A., \& Berruga, M. I. (2011). Efecto de la exposición al aire en la evolución del color en queso de oveja con azafrán. XXXVI Congreso de la sociedad española de ovinotecnia y caprinotecnia (pp. 139-142). San Sebastián (Spain): SEOC.

Licón, C. C., Carmona, M., Molina, A., \& Berruga, M. I. (2012). Chemical, microbiological, textural, color, and sensory characteristics of pressed ewe milk cheeses with saffron ( Crocus sativus L .) during ripening. Journal of Dairy Science, 95(8), 4263-4274. https://doi.org/10.3168/jds.2012-5389.

Li, J. H., Miao, J., Wu, J. L., Chen, S. F., \& Zhang, Q. Q. (2014). Preparation and characterization of active gelatin-based films incorporated with natural antioxidants. Food Hydrocolloids, 37, 166-173. https://doi.org/10.1016/j.foodhyd.2013.10.015.

Mallikarjunan, P., Chinnan, M., Balasubramaniam, V., \& Phillips, R. (1997). Edible coatings for deep-fat frying of starchy Products1. Lebensmittel-Wissenschaft UndTechnologie, 30(7), 709-714. https://doi.org/10.1006/fstl.1997.0263.

Martins, J. T., Cerqueira, M. A., \& Vicente, A. A. (2012). Influence of $\alpha$-tocopherol on physicochemical properties of chitosan-based films. Food Hydrocolloids, 27(1), 220-227. https://doi.org/10.1016/j.foodhyd.2011.06.011.

Nielsen, C. K., Kjems, J., Mygind, T., Snabe, T., \& Meyer, R. L. (2016). Effects of Tween 80 on growth and biofilm formation in laboratory media. Frontiers in Microbiology, 7, 1-10. https://doi.org/10.3389/fmicb.2016.01878.

Ollé Resa, C. P., Jagus, R. J., \& Gerschenson, L. N. (2014). Natamycin efficiency for controlling yeast growth in models systems and on cheese surfaces. Food Control, 35(1), 101-108. https://doi.org/10.1016/j.foodcont.2013.06.049.

Ortiz de Elguea-Culebras, G. (2017a). Biological activities of essential oils and related byproducts from the industrial distillation of Hyssopus officinalis L. Lavandula $x$ intermedia Emeric ex Loisel var. Super and Santolina chamaecyparissus: Applications on cheese industry and bioplaguicide development. University of Castilla-La Mancha.

Ortiz de Elguea-Culebras, G., Berruga, M. I., Santana-Méridas, O., Herraiz-Peñalver, D., \& Sánchez-Vioque, R. (2017b). Chemical composition and antioxidant capacities of four mediterranean industrial essential oils and their resultant distilled solid by-products. European Journal of Lipid Science and Technology, 1-10. https://doi.org/10.1002/ejlt. 2017002421700242

Ortiz de Elguea-Culebras, G., Sánchez-Vioque, R., Santana-Méridas, O., Herraiz-Peñalver, D., Carmona, M., \& Berruga, M. I. (2016). In vitro antifungal activity of residues from essential oil industry against Penicillium verrucosum, a common contaminant of ripening cheeses. LWT - Food Science and Technology, 73, 226-232. https://doi.org/10. 1016/j.lwt.2016.06.008.

Owolarafe, O. K., Olabige, T. M., \& Faborode, M. O. (2007). Macro-structural characterisation of palm fruit at different processing conditions. Journal of Food Engineering, 79(1), 31-36. https://doi.org/10.1016/j.jfoodeng.2006.01.024.

Plascencia-Jatomea, M., Viniegra, G., Olayo, R., Castillo-Ortega, M. M., \& Shirai, K. (2003). Effect of chitosan and temperature on spore germination of Aspergillus Niger. Macromolecular Bioscience, 3(10), 582-586. https://doi.org/10.1002/mabi. 200350024.

Ponce, A. G., Roura, S. I., del Valle, C. E., \& Moreira, M. R. (2008). Antimicrobial and antioxidant activities of edible coatings enriched with natural plant extracts: In vitro and in vivo studies. Postharvest Biology and Technology, 49(2), 294-300. https://doi org/10.1016/j.postharvbio.2008.02.013.

Quintana-Obregón, E. A., Plascencia-Jatomea, M., Sánchez-Mariñez, R. I., Rosas-Burgos, E. C., \& Cortez-Rocha, M. O. (2010). Inhibición del crecimiento radial" in vitro" de la Fusarium verticillioides en presencia de quitosano. Revista Iberoamericana de Polímeros, 11(6), 386-391.

Rutz, J. K., Zambiazi, R. C., Borges, C. D., Krumreich, F. D., Da Luz, S. R., Hartwig, N., et al. (2013). Microencapsulation of purple Brazilian cherry juice in xanthan, tara gums and xanthan-tara hydrogel matrixes. Carbohydrate Polymers, 98(2), 1256-1265. https://doi.org/10.1016/j.carbpol.2013.07.058.

Sabaghi, M., Maghsoudlou, Y., Khomeiri, M., \& Ziaiifar, A. M. (2015). Active edible coating from chitosan incorporating green tea extract as an antioxidant and antifungal on fresh walnut kernel. Postharvest Biology and Technology, 110, 224-228. https://doi.org/10.1016/j.postharvbio.2015.08.025.

Sánchez-Vioque, R., Izquierdo-Melero, M. E., Polissiou, M., Astraka, K., Tarantilis, P. A. Herraiz-Peñalver, D., et al. (2015). Comparative chemistry and biological properties of the solid residues from hydrodistillation of Spanish populations of Rosmarinus officinalis L. Grasas y Aceites, 66(2), 1-18. https://doi.org/10.3989/gya.1060142.

Sánchez-Vioque, R., Polissiou, M., Astraka, K., Mozos-Pascual, M. de los, Tarantilis, P., Herraiz-Peñalver, D., et al. (2013). Polyphenol composition and antioxidant and metal chelating activities of the solid residues from the essential oil industry. Industrial Crops and Products, 49, 150-159. https://doi.org/10.1016/j.indcrop.2013. 04.053.

Serrano-Martinez, C. E. (1997). Estudio de la micoflora del queso manchego con denominacion de origen. Junta de Comunidades de Castilla-La Mancha.

Shahbazi, Y. (2017). The properties of chitosan and gelatin films incorporated with ethanolic red grape seed extract and Ziziphora clinopodioides essential oil as biodegradable materials for active food packaging. International Journal of Biological Macromolecules, 99, 746-753. https://doi.org/10.1016/j.ijbiomac.2017.03.065.

Sharafati-Chaleshtori, F., \& Sharafati-Chaleshtori, R. (2017). In vitro antibacterial and antioxidant properties of Elettaria cardamomum Maton extract and its effects, incorporated with chitosan, on storage time of lamb meat. Veterinarski Arhiv, 87(3), 301-315. https://doi.org/10.24099/vet.arhiv.160117.

Siripatrawan, U., \& Harte, B. R. (2010). Physical properties and antioxidant activity of an active film from chitosan incorporated with green tea extract. Food Hydrocolloids, 
24(8), 770-775. https://doi.org/10.1016/j.foodhyd.2010.04.003.

Souza, B. W. S., Cerqueira, M. A., Casariego, A., Lima, A. M. P., Teixeira, J. A., \& Vicente, A. A. (2009). Effect of moderate electric fields in the permeation properties of chitosan coatings. Food Hydrocolloids, 23(8), 2110-2115. https://doi.org/10.1016/j. foodhyd.2009.03.021.

Souza, V. G. L., Fernando, A. L., Pires, J. R. A., Rodrigues, P. F., Lopes, A. A. S., \& Braz Fernandes, F. M. (2017). Physical properties of chitosan films incorporated with natural antioxidants. Industrial Crops \& Products, 107, 565-572. https://doi.org/10 1016/j.indcrop.2017.04.056.

Voon, H. C., Bhat, R., \& Rusul, G. (2012). Flower extracts and their essential oils as potential antimicrobial agents for food uses and pharmaceutical applications. Comprehensive Reviews in Food Science and Food Safety, 11(1), 34-55. https://doi.org/ 10.1111/j.1541-4337.2011.00169.x.

Xie, W., Xu, P., \& Liu, Q. (2001). Antioxidant activity of water-soluble chitosan derivatives. Bioorganic and Medicinal Chemistry Letters, 11(13), 1699-1701. https:// doi.org/10.1016/S0960-894X(01)00285-2.

Yoksan, R., Jirawutthiwongchai, J., \& Arpo, K. (2010). Encapsulation of ascorbyl palmitate in chitosan nanoparticles by oil-in-water emulsion and ionic gelation processes. Colloids and Surfaces B: Biointerfaces, 76(1), 292-297. https://doi.org/10. 1016/j.colsurfb.2009.11.007.

Zabka, M., \& Pavela, R. (2013). Antifungal efficacy of some natural phenolic compounds against significant pathogenic and toxinogenic filamentous fungi. Chemosphere, 93(6), 1051-1056. https://doi.org/10.1016/j.chemosphere.2013.05.076.

Ziani, K., Oses, J., Coma, V., \& Maté, J. I. (2008). Effect of the presence of glycerol and Tween 20 on the chemical and physical properties of films based on chitosan with different degree of deacetylation. LWT - Food Science and Technology, 41(10), 2159-2165. https://doi.org/10.1016/j.lwt.2007.11.023. 